Brit. J. vener. Dis. (1966), 42, 197.

\title{
RELATIONSHIP OF CANDIDA ALBICANS IN THE GENITAL AND ANORECTAL TRACTS*
}

\author{
BY
}

\author{
J. J. ROHATINER
}

Guy's Hospital, London

The terms Monilia and Moniliasis, still widely used to denote thrush infections, are taxonomically incorrect. The name Monilia, first used by John Hill (1748-52), now applies to certain fruit-rotting fungi. The generic name Candida, in use since 1923, was informally agreed upon at the III Microbiological Congress in New York in 1939, and was finally adopted at the VIII International Botanical Congress in Paris in 1954. A memorandum of the Medical Research Council in 1958 describes it as a "designation now generally accepted" (Med. Res. Coun. Memo. No. 23, 1958). Candida albicans is its principal but not the sole pathogenic member.

There is convincing evidence that other species of Candida frequently cause disease in man. Hurley and Morris (1964) review this evidence and correlate the presence of certain species of yeast-like fungi other than $C$. albicans with superficial disease of the vagina; Hurley (1965) considers the tendency to regard $C$. albicans as the only member of the genus Candida causing human disease or experimental disease in animals a "regrettable misconception".

* Received for publication April 9, 1965
It has been known for a long time that Candida species are found as saprophytes in the female genital and alimentary tracts. It is also accepted by several workers that the intestinal reservoir of Candida is probably one of the main sources, or possibly the main source, of infection in candidial vulvovaginitis (de Sousa and van Uden, 1960). Yet, while there exist many excellent studies concerning the incidence of Candida in the bowel and genitourinary tract, it appears that no specific investigation of their mutual relationship has been undertaken.

In the last few years (probably because of the wide use of antibiotics) thrush is said to have ousted Trichomonas vaginalis in the United States of America as the principal cause of inflammatory lesions of the female genital tract (Pace and Schantz, 1957). Figures from Guy's Hospital since 1962 confirm this statement.

Table I shows the incidence of asymptomatic candidiasis of the vagina. In Great Britain it varies from 4.6 to 7.6 per cent. Somewhat higher figures are found in American and Italian studies. The incidence of Candida is yet higher in the genital tracts of pregnant women and in diabetics.

TABLE I*

INCIDENCE OF ASYMPTOMATIC CANDIDA ALBICANS IN THE VAGINA

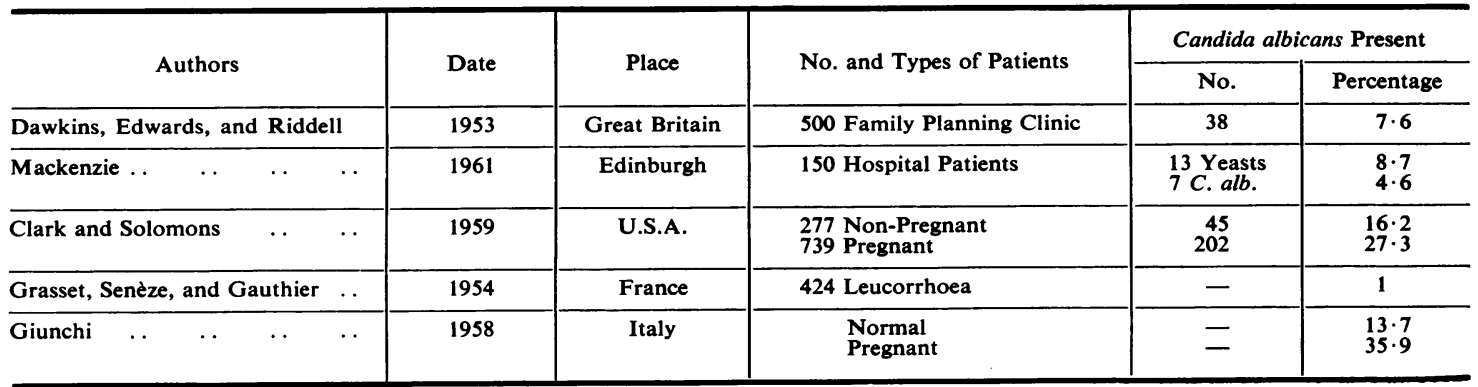

* Modified after Winner and Hurley (1964) 
The occurrence of Candida albicans in faeces (see Table II) shows an almost identical prevalence (27 per cent.) in two recent studies in Great Britain, and a somewhat wider range (16.9 to 37.7 per cent.) in the United States. Much higher figures are found in hot climates and in countries with lower standards of sanitation. A series in Mexico yielded 40 per cent.; another, in Baghdad, 70 per cent. (Akrawi, 1960). A very high proportion of persons recently treated with antibiotics have Candida in the alimentary tract: 85 per cent. in a series in Argentina and 86 per cent. in a similar study in Brazil (Silveira and Correia, 1960).

\section{Material and Methods}

\section{Present Study}

150 female patients attending the Venereal Diseases Department at Guy's Hospital were studied. Women who were pregnant or who had recently been treated with broad-spectrum antibiotics, corticosteroids, or cytotoxic agents were excluded as such drugs may enhance candidiasis. Diagnosis was based on clinical symptoms and the finding of Candida albicans in stained smears and cultures of the vaginal secretions and faeces.

Gram-stained smears accompanied by wet films were examined immediately. Vaginal and cervical secretions were plated on chocolate agar (McLeod) and incubated at $37^{\circ} \mathrm{C}$. for $48 \mathrm{hrs}$. Coverslips on the surfaces of the inoculated media to promote anaerobiasis were used on some subcultures.

All faecal specimens were cultured at least twice on Sabouraud's medium and incubated at $37^{\circ} \mathrm{C}$; ; again coverslips were used on some subcultures.

A few doubtful cultures were confirmed or identified by fermentation tests. Cultural examination is considered essential as the error in the diagnosis of vaginal candidiasis by stained and wet-film technique combined with "clinical impression" is sometimes as great as 60 per cent. (O’Brien, 1964).

\section{Results}

43 of the 150 patients studied were found to have vulvovaginal candidiasis; three more had blastospores in the vagina but had no clinical symptoms and were therefore not treated. 21 of the 43 patients (48 per cent.) treated for infection with Candida were found to have Candida albicans in the faeces (Table III). Five other patients had other members of the Candida group but not $C$. albicans. A further more recent, series of over 220 patients (not included in this study) yielded an almost identical figure ( $48 \cdot 2$ per cent.).

TABLE III

OCCURRENCE OF CANDIDA ALBICANS IN FAECES IN PATIENTS WITH GENITAL CONDITIONS

\begin{tabular}{l|l|l}
\hline \multicolumn{1}{c|}{ Sex } & \multicolumn{1}{|c}{ Findings } & No. of Cases \\
\hline Female & $\begin{array}{l}\text { Yeasts and } \text { C. albicans } \\
\text { C. albicans only } \\
\text { Total }\end{array}$ & $\begin{array}{l}26 \\
21\end{array}$ \\
\hline Male & $\begin{array}{l}\text { Consorts examined } \\
\text { C. albicans }\end{array}$ & 63 \\
\hline
\end{tabular}

The average incidence of Candida albicans in the faeces in Great Britain is 27 per cent.; the higher incidence of 48 per cent. found among patients with vaginal candidiasis suggests that the intestinal pool may be an important source of infection in women with this condition.

\section{Treatment}

This usually consisted of two Nystatin pessaries inserted nightly for 10 to 15 days, combined with oral Nystatin, 0.5 M.U. three times a day for 7 days if Candida was found in the alimentary tract.

Local treatment had to be repeated in eight patients and three had more than two combined

TABLE II*

OCCURRENCE OF CANDIDA ALBICANS IN FAECES

\begin{tabular}{|c|c|c|c|c|c|c|c|c|}
\hline \multirow{2}{*}{\multicolumn{3}{|c|}{ Authors }} & \multirow{3}{*}{$\begin{array}{l}\text { Date } \\
1961\end{array}$} & \multirow{3}{*}{$\begin{array}{c}\text { Place } \\
\text { Edinburgh }\end{array}$} & \multirow{2}{*}{ Series } & \multirow{2}{*}{ No. of Cases } & \multicolumn{2}{|c|}{ Percentage with } \\
\hline & & & & & & & All Yeasts & C. albicans \\
\hline Mackenzie & .. & .. & & & Hospital Patients & 103 & 34 & 27 \\
\hline \multicolumn{3}{|c|}{$\begin{array}{c}\text { Artagaveytia-Allende } \\
\text { and García-Zorrón }\end{array}$} & 1956 & Mexico & Healthy Subjects & 80 & 一 & 40 \\
\hline Winner & $\cdots$ & $\cdots$ & 1960 & London & Hospital Patients & 239 & - & $27 \cdot 2$ \\
\hline Schnoor & $\cdots$ & $\cdots$ & 1939 & U.S.A. & Healthy Subjects & 314 & $33 \cdot 1$ & $16 \cdot 9$ \\
\hline Felsenfeld & . & $\cdots$ & 1944 & U.S.A. & $\begin{array}{l}\text { Newly admitted patients } \\
\text { Chronically institutionalized }\end{array}$ & $\begin{array}{l}300 \\
600\end{array}$ & 二 & $\begin{array}{l}19 \cdot 3 \\
37 \cdot 7\end{array}$ \\
\hline Symposium & & $\cdots$ & 1957 & Argentine & $\begin{array}{l}\text { Children treated with antibiotics } \\
\text { Untreated children }\end{array}$ & 二 & 二 & $\begin{array}{l}85 \cdot 2 \\
56 \cdot 3\end{array}$ \\
\hline
\end{tabular}

*Modified after Winner and Hurley (1964). 
courses, including local ointment and change of pessaries. One had to be treated with gentian violet. There were no failures and all patients eventually became free from infection with Candida.

The criterion of cure was the absence of Candida in two consecutive smears and cultures taken not earlier than 4 weeks after treatment. Equally, absence of Candida in two consecutive samples of faeces was considered proof of successful oral treatment.

\section{Consorts}

Only four of the 28 male consorts investigated had candidial balanitis; two suffered from candidial urethritis. In one of the latter the fungus was also cultured from midstream urine. Nineteen further male consorts were found to be suffering from other genital infection (see Table IV). Fifteen had nonspecific urethritis, four had gonococcal urethritis. Only three of the 28 male consorts examined had no genital disorder at all. The surprising amount of male non-specific urethritis which came to light seemed to be large enough to justify further investigation.

TABLE IV

INCIDENCE OF CANDIDA ALBICANS IN 150 FEMALE AND 28 MALE CONSORTS

\begin{tabular}{|c|c|c|}
\hline Sex & Findin & \\
\hline Female & $\begin{array}{l}\text { Total examined } \\
\text { No. with genital Candida ... } \\
\text { No. with other simultaneous } \\
\text { infection }\end{array}$ & $\begin{array}{c}150 \\
46 \text { ( } 30 \text { per cent.) } \\
7\end{array}$ \\
\hline Male & $\begin{array}{l}\text { Total examined } \\
\text { No. with Candida ... } \\
\text { No. with other genital in- } \\
\text { fection } \ldots\end{array}$ & $\begin{array}{r}28 \\
6 \\
19\end{array}$ \\
\hline
\end{tabular}

Discussion
There could be several interpretations of these results. Different investigators since Stoecklin (1898) have suggested that the pathogenicity of the thrush fungus might be modified by the presence and interaction of bacilli. Winner and Hurley (1964) point out that this observation of Stoecklin foreshadowed the modern work on the inter-relationship between micro-organisms. There is, for instance, evidence of a natural balance in the "normal" buccal cavity, and possibly also in the vagina, between Candida albicans and lactobacilli, the former providing a growth factor-a member of the vitamin B group-for the latter (Wilson and Goaz, 1959); the lactobacilli in turn inhibit the multiplication and activity of Candida albicans by the production of lactic acid. A similar relationship has been observed between yeasts and staphylococci (Virtanen,
1951), and yeasts and lactobacilli (Young, Krasner, and Yudkofsky, 1956; Guillot, 1958).

Other studies demonstrated a growth factor for Mycobacterium tuberculosis in the polysaccharide fraction of cell-free extracts of $C$. albicans. This fraction stimulated in particular the growth of tubercle bacilli which had been inhibited by streptomycin. Both the living cells of $C$. albicans and the extracted polysaccharide enhanced the evolution of experimental tuberculosis in mice (Mankiewicz and Liivak, 1960). A special cultural method for the detection of tuberculosis has been developed in America, by making use of the observation that Mycobacterium tuberculosis will alter a selective dye, so as to prevent its lethal action on Candida albicans (Mankiewicz, 1957), and this has been confirmed by Kawamori, Kawai, and Asahara (1961); Yamabayashi (1958) showed that Candida albicans contained a substance that enhanced the virulence of Proteus vulgaris and Pseudomonas aeruginosa.

Similarly, it is possible that the male consorts in our series might, by their promiscuity, have infected their partners and thereby changed the pathogenicity of the saprophytic yeasts present in the urogenitary tracts of the women. Or the females might have had in their vaginal flora certain bacteria or viruses which by themselves, or enhanced through the presence of Candida, produced a nonspecific urethritis in the male.

Recent microbiological investigations have elucidated the mechanism by which the viral component of mixed infections enhances the pathogenic effects of the bacterial component.

The viral component apparently suppresses some cellular defence mechanism (Buddingh, 1963). This would explain a certain success of antibiotic treatment in viral infections. Buddingh (1965) thinks that "Early therapy apparently catches the bacterial infection at the right moment, when multiplication is most rapid"; he emphasizes that this process in combined infections is in no sense a "one-way" reaction. "Just as the virus increases bacterial virulence, the bacteria exert a marked inhibitory, though not completely suppressive, effect on the virus. ... Implicit in this observation is the likelihood that antiviral agents may very well be derived from bacterial factors very much as antibacterials have been derived from fungi."

Another possibility is an allergic response to toxins liberated by Candida. Maibach and Kligman (1962), who succeeded in producing experimental dermatitis by both live and dead suspensions of Candida, claim that there exists a very strong bond between the cells and such toxins. Winner (1966) 
lists amongst features noted in experimental Candida infection in animals ". . . superimposition of allergy and failure of antibodies to protect". He states that derangements of immunity mechanisms are common features in human and animal candidial disease. Forman (1965) has observed several cases of balanitis and balano-posthitis, caused, in his opinion, by an allergic reaction to Candida.

\section{Summary}

Thrush appears now to be the principal cause of vulvovaginitis. Of 150 female patients who attended the Venereal Diseases Department at Guy's Hospital, 46 were found to harbour Candida albicans in the genito-urinary tract, and 43 of these were suffering from candidial vulvovaginitis and received treatment. This represents an incidence of 28.8 per cent. as compared with findings of 4.5 to 7.5 per cent. asymptomatic carriers of Candida albicans in recent British studies.

48 per cent. of patients with candidial vulvovaginitis also had Candida in the alimentary tract. A further series of over 200 patients (not included in this study) yielded an almost identical figure, $48 \cdot 2$ per cent. This compares with 27 per cent. of a hospital population found to be carriers in Great Britain, and these figures indicate that the intestinal reservoir is probably a major source of vulvovaginal infection.

A comparatively large number of the male consorts of these patients suffered from non-specific urethritis. This suggests that candidial vulvovaginitis may be an important aetiological factor in urethritis of doubtful causation in the male.

My thanks are due to Dr Alan S. Grimble, head of the Venereal Diseases Department at Guy's Hospital, for his constant encouragement and many invaluable suggestions. I should also like to thank the nursing staff of the department, especially $\mathrm{Mr} \mathrm{D}$. Cobell, for their willing help.

\section{REFERENCES}

Akrawi, Y. Y. (1960). J. Fac. med. Baghdad, 2, 63.

Artagaveytia-Allende, R. C., and Garcia-Zorron, N. (1956). Ciencia (Méx), 16, 212.

Buddingh, G. H. (1963). Amer. J. Path., 43, 407. (1965). Antibiotic News, 1, (2), 1.

Clark, D. H., and Solomons, E. (1959). Amer. J. Obstet. Gynec., 78, 1314.

Dawkins, S. M., Edwards, J. M. B., and Riddell, R. W. (1953). Lancet, 2, 1230.

De Sousa, H. M., and Van Uden, N. (1960). Amer. J. Obstet. Gynec., 80, 1096.

Felsenfeld, O. (1944). Amer. J. med. Sci., 207, 60.

Forman, L. (1965). Personal communication.

Giunchi, G. (1958). Sci. med. ital. (Engl. Ed.), 2 ser., 6, 580.
Grasset, J., Senèze, J., and Gauthier, R. (1954). Bull. Féd. Soc. Gynéc. Obstét. franc., 6, 181.

Guillot, N. (1958) Ann. Inst. Pasteur., 95, 194.

Hill, J. (1748-52). "A General Natural History: or New and Accurate Descriptions of the Animals, Vegetables, and Minerals of the Different Parts of the World" (3 vols). Osborne, London.

Hurley, R. (May, 1965). Personal communication.

and Morris, E. D. (1964). J. Obstet. Gynaec. Brit. Cwlth., 71, 692.

Kawamori, T., Kawai, J., and Asahara, Y. "Studies in Candidiasis in Japan". Tokyo.

Mackenzie, D. W. R. (1961). Sabouraudia, 1, 8.

Maibach, H. I., and Kligman, A. M. (1962). Arch. Derm. (Chicago), 85, 233.

Mankiewicz, E. (1957). Amer. Rev. Tuberc., 75, 836.

and Liivak, M. (1960). Nature (Lond.), 187, 250.

O'Brien, J. R. (1964). Canad. med. Ass. J., 90, 1073.

Pace, H. R., and Schantz, S. I. (1957). Monogr. on Ther., 2,29 .

Schnoor, T. G. (1939). Amer. J. trop. Med., 19, 163.

Silveira, J. S., and Correia, J. U. (1960). Hospital (Rio de J.), 58, 333.

Stoecklin, H. de (1898). Arch. Méd. exp., 10, 1.

Symposium on Moniliasis (1957). Rev. Asoc. med. argent., 71, 2.

Virtanen, I. (1951). Ann. Med. exp. Fenn., 29, 352.

Wilson, T. E., and Goaz, P. W. (1959). J. dent. Res., 38, 1044.

Winner, H. I. (1960). Unpublished data on the incidence of Candida albicans in sputum and faeces. (1966) "Squibb Symposium on Candida albicans". London. (In the press).

and Hurley, R. (1964). "Candida Albicans", 1st ed., pp. 34 and 39; and Tables 10 and 11, pp. 125 and 135. Churchill, London.

Yamabayashi, H. (1958). Med.J. Osaka Univ., 9, 11.

Young, G., Krasner, R. I., and Yudkofsky, P. L. (1956). J. Bact., 72, 525.

\section{Le rapport entre le Candida albicans et les voies génitales ano-rectales \\ RÉSUMÉ}

Le muguet semble maintenant être la cause principale de la vulvo-vaginite. 46 des 150 patientes qui ont rendu visite au dispensaire anti-vénérien de Guy's Hospital avaient les voies uro-génitales infectées par le Candida albicans, et $\mathbf{4 3}$ des $\mathbf{4 6}$ souffraient de vulvo-vaginite causée par le Candida albicans et ont été traitées. Cela représente un taux de 28,8 pour cent comparé au taux de 4,5 à 7,5 pour cent de porteuses de Candida albicans sans symptômes dans les récentes études britanniques.

48 pour cent des patientes souffrant de vulvo-vaginite avaient aussi une infection du canal alimentaire par le Candida albicans. Dans une autre série de plus de 220 malades (hors de cette étude) 48.2 pour cent furent infectes, tandis que 27 pour cent de la population hospitalière est porteuse en Grande Bretagne; ces chiffres indiquent que le réservoir intestinal est probablement la source principale de l'infection vulvo-vaginale.

En comparison un grand nombre des conjoints de ces patientes souffraient d'urétrite non-gonococcique. Cela suggère que la vulvo-vaginite causée par le Candida albicans peut être un important facteur étiologique de l'urétrite d'origine douteuse chez l'homme. 